\title{
A Comparative study on the effects of Yaji (Suya Meat sauce) and its spice constituents on the male reproductive profile of adult male Sprague Dawley rats
}

\author{
Adejoke Elizabeth Memudu ${ }^{1}$, Francis Ikechukwu Duru² \\ ${ }^{1}$ Department of Anatomy, College of Medical Sciences, Edo State University Uzairue (formerly Edo State \\ University Iyamho) Edo State, Nigeria \\ 2Department of Anatomy, College of Medicine, University of Lagos, Lagos State, Nigeria
}

Congress: Presented at the Anatomical Society of Nigeria

\begin{abstract}
Objective: This comparative study was designed to analyze the potential effects of Yaji (suya meat sauce) and its composite spices on male fertility based on testicular histology, serum testosterone level, and semen analysis parameters.

Methods: The study included 70 adult male Sprague Dawley rats with an average weight of $120 \mathrm{~g}$. They were divided into two experimental study groups, respectively analyzed for 28 and 56 days. Each group featured 35 rats, further subdivided into seven treatment groups ( $A-G$; $\mathrm{n}=5$ each). Group A - Control; Group B: $200 \mathrm{mg} / \mathrm{kg}$ of Yaji; Group C: $200 \mathrm{mg} / \mathrm{kg}$ of red pepper; Group D: 200 $\mathrm{mg} / \mathrm{kg}$ of black pepper; Group E: $200 \mathrm{mg} / \mathrm{kg}$ of clove; Group F: $200 \mathrm{mg} / \mathrm{kg}$ of ginger; and Group G: $200 \mathrm{mg} /$ $\mathrm{kg}$ of garlic given orally using an oral cannula. At the end of the experiment, the animals were euthanized. Blood samples collected via cardiac puncture and their testes were excised and weighed. The cauda epididymis was excised for semen analysis using a Neubauer Counting Chamber (hemocytometer) and the testes were fixed in Bouin solution, processed, and stained with Hematoxylin and Eosin.
\end{abstract}

Results: Significant increases $(p<0.05)$ were seen in body weight, testicular weight, serum testosterone level, sperm count and motility in the Yaji treated groups, in addition to significant increases in serum testosterone level, sperm counts, and sperm motility, and enhanced spermatogenesis and proliferation of Leydig cells in vivo as compared to the groups given isolated component spices (groups C-G), which also showed significant changes in testosterone and semen analysis when compared with the control groups.

Conclusions: Yaji or its spice components can boost male fertility parameters when consumed in moderated quantities without the known cytotoxic additives or condiments such as monosodium glutamate.

Keywords: Yaji, spermatogenesis, Leydig cells, testosterone, sperm count

\section{INTRODUCTION}

Yaji, made from a mixture of different pungent tasting spices and also referred to as local curry powder, is used for spicing various local dishes such as Suya (a meat delicacy), gusgus, fatte, and daffa-duja in the Hausa community in Nigeria (Wall, 1998; Erhirhie, 2019). In Nigeria, spices are rarely consumed as a single flavoring agent, but rather combined with several spices with or without additives or condiments (Ugwuja et al., 2007; Erhirhie, 2019). Yaji contains the following spices: finely ground roasted peanuts; red pepper; black pepper; garlic; onion powder; groundnut cake; ginger; and cloves with or without additives or condiment such as white Maggi - popularly called Ajinomoto- in Nigeria (Igene \& Mohammed, 1983; Okonkwo, 1987; Nwaopara et al., 2004; Omojola, 2008); other ingredients include table salt (sodium chloride) and sometimes fine cornmeal (Wright, 2005). Yaji component spices have been documented in the treatment of male sexual dysfunction in Ayurvedic medicine (Vijayakumar et al., 2004). It is important to note that Hausa male folks believe that some traditional or herbal aphrodisiacs such as Yaji, hakinmaye, and stimi help to enhance sexual performance, a belief that has made these spices highly consumed by men, most especially in the Northern part of Nigeria and in Niger Republic, for their supposed effects on sexual appetite stimulation and stamina (Uzeh et al., 2006; Nwaopara et al., 2008; Ezejindu et al., 2014). Scientific reports documented that the active compounds present in Yaji spices are potentially harmful when consumed in excess (Southgate, 1993; Nwaopara et al., 2008; Ukoha et al., 2014). The active compounds in Yaji include gingerol found in ginger (Wichtl, 2004), eugenol in cloves, capsaicin in red peppers, piperine in black pepper (Surh \& Lee, 1995; Krishnaswamy \& Raghuramulu, 1998; McGee, 2004) and allicin in garlic (Macpherson et al., 2005), each with documented adverse effects on testicular and male fertility parameters when consumed in isolation (Nwaopara et al., 2004). Some studies have documented liver adverse effects, with mild patchy necrosis of the hepatocytes and signs of hepatitis (Vijayakumar et al., 2004; Nwaopara et al., 2007), whereas in the kidneys distinct basophilic bodies have been found in the interstitium of the renal cortex (Nwaopara et al., 2008). Considering the inherent chemical properties/potential of all active constituents present in Yaji, it might be fitting to say that Yaji is indeed a chemically complex spice (Akpamu et al., 2011a). The spice combination found in Yaji makes it a good flavoring ingredient for different foods and dishes, which explains its massive consumption in Northern Nigeria (Uzeh et al., 2006).

A wide range of studies have reported deleterious effects of Yaji in major organs such as the pancreas, liver, kidneys, and brain, with effects ranging from cellular distortion, necrosis, to degeneration in the mentioned organs (Nwaopara et al., 2004; 2007; 2008; 2009; 2010). In Nigeria, there is a growing concern about the excessive consumption of this spice, which has been apportioned without a standard dosage or serving method (Nwaopara et al., 2010) and consumed mostly by men (Alley \& Burroughs, 1991). The side effects of dieting on the male reproductive system also include some beneficial effects in the treatment of reproductive system disorders associated with flavonoid and antioxidant compounds (Hossei$\mathrm{ni}, 2018)$. Oxidative stress can potentiate male infertility, thereby affecting parameters such as sperm motility, sperm count, and spermatogenesis (Eskenazi et al., 2005). However, consumption of food, spice, or diets containing vitamin C, vitamin E, zinc, folic acid, copper, selenium, and other phytochemicals with antioxidant properties may improve and protect one's fertility status (Robbins et al., 2012). Scientists need to advocate for continuous fertility health awareness and the importance of nutrition in reproductive health and in the prevention of fertility problems 
(Lo, 2000; Safarinejad et al., 2010), by further connecting the science of nutrition to preventive medicine. Regulation of male dietary pattern is known to be an important component of reproductive health (Bhargava \& Guthrie, 2002; Kopelman \& Caterson, 2005).

Hence, this study was designed to evaluate the effects of Yaji and its isolated constituent spices on male fertility. This study presents protocols and results of a wider and deeper evaluation of the effect of Yaji and its isolated constituent spices, including elements such as hormonal assays (for testosterone levels), semen analysis, testicular histology, and assessment of effects on body and organ weights to further the knowledge about the extent to which Yaji and its spice mixture may affect male fertility and add to scarce literature produced on the subject. Semen analysis is a significant concept in infertility investigation of herbal compounds, drugs, or supplements taken as a measure to improve male fecundity in clinical andrology and male fertility (Vasan, 2011).

\section{MATERIAL AND METHODS}

\section{Experimental animals}

Seventy healthy adult male Sprague Dawley rats aged about two months with an average weight of $120 \mathrm{~g}$ were included in this study. They were cared for according to the animal care guidelines documented in the "Guide for the Care and Use of Laboratory Animals" (National Research Council (US) Committee for the Update of the Guide for the Care and Use of Laboratory Animals, 2011). The animals were procured from Covenant Farm (Nig.) Enterprises, Gbolasire Estate; Iwo road Ibadan, Oyo State, Nigeria. They were authenticated in the Department of Zoology, University of Lagos, Nigeria, and then housed in the Animal House of the Department of Anatomy, University of Lagos, Nigeria, where they were kept in well-ventilated rat metallic cages under standard laboratory condition (12hrs light: $12 \mathrm{hrs}$ dark cycle; temperature-: $37.5^{\circ} \mathrm{C} ; 40-55 \%$ humidity). They were allowed to acclimatize for two weeks before experimentation and fed pelleted rat feed from UAC, Vital Feeds Lagos, Nigeria, and water ad libitum.

\section{Research material: Yaji (Suya Sauce)}

Yaji spice preparation was performed according to the method described by Nwaopara et al. (2004) without additives. The composition of Yaji for this study was as follows: dried fruits of Zingiber officinale (rhizomes of ginger), Syzygium aromaticum (clove buds), dried Capsicum annum (Red pepper), Allium sativum (garlic), and Pipier guineese (black pepper) as reported by Erhirhie (2019) procured in Lawanson market in Surulere, Lagos, Nigeria. Spice fruits were taken to the Botany Department, University of Lagos, Nigeria, for identification and authentication where a voucher specimen was deposited.

Preparation of the aqueous extract of Yaji (Suya Sauce) and its spice constituents

The quantities of ingredients in commercially produced Yaji sauce are usually not standardized (Ezejindu et al., 2014). In this study, Yaji was made by mixing dried powdered spice constituents, which were later macerated into an aqueous solution. Equal portions of each ground spice [dried fruits of Zingiber officinale (rhizomes of ginger), Eugenia aromaticum (dried clove buds), Capsicum annum (Red pepper), Allium sativum (garlic) and Pipier guineese (black pepper)] were mixed to form the Yaji sauce. Then, $10 \mathrm{~g}(10,000 \mathrm{mg})$ of Yaji and each of the six isolated ingredients named above were macerated in $50 \mathrm{ml}$ of distilled water in different labeled containers, to obtain a concentration of $200 \mathrm{mg} / \mathrm{ml}$. No previous studies have looked into the therapeutic effect of this dose of Yaji, although Memudu et al. (2015) analyzed the effects of garlic and black pepper at $200 \mathrm{mg} / \mathrm{kg}$.

\section{Experimental Animals Grouping}

Group A - Control; Group B: 200 mg/kg of Yaji; Group C: $200 \mathrm{mg} / \mathrm{kg}$ of red pepper; Group D: $200 \mathrm{mg} / \mathrm{kg}$ of black pepper; Group E: $200 \mathrm{mg} / \mathrm{kg}$ of cloves; Group F: $200 \mathrm{mg} /$ $\mathrm{kg}$ of ginger; and Group G: $200 \mathrm{mg} / \mathrm{kg}$ of garlic. The ingredients wee administered orally using an oral cannula for 28 days and 56 days, respectively

\section{Oral administration of aqueous extract of Yaji} sauce and its spices

Each animal was given $1 \mathrm{ml}$ of the crude extract of Yaji and its isolated spice components for 28 days according to the method described by Zodape \& Gaikwad (2019) and for 56 days based on the method described by Chinta et al. (2017) and Ekaputri et al. (2018) via oral cannula. The lengths of administration were based on the spermatogenic cycle of rats, which lasts for 55 days on an average (Chinta et al., 2017).

Euthanasia of experimental animals: A day after the administration of the last dose, the experimental animals final body weights were taken before they were euthanized via intraperitoneal injection of $50 \mathrm{mg} / \mathrm{ml}$ of ketamine (Claris life Sciences Ltd, India).

Blood collection for serum biochemical analysis: Blood was collected via cardiac puncture using a $5 \mathrm{ml}$ capacity syringe inserted into the left ventricle. The collected blood sample were transferred into a labeled plain specimen bottles. They were arranged in a centrifuge machine and spun at 2,500 r.p.m. for 10 minutes to obtain serum. Decanted serum was placed in a plain cuvette and frozen for Serum testosterone Spectrophotometric analysis using Enzyme-linked immunoassay (ELISA) test kits made by BIOTEC Laboratories, U.K. The test kits used were made by BIOTEC Laboratories Ltd, 32 Ansons Road Martlesham Heath, UK.

\section{Testicular tissue collection for histopathology analysis \\ The animals were dissected, an incision was made in} the lower abdominal wall and the testes pushed out from the scrotal sac. The testes were quickly excised and their wet weight measured using an analytical weighing scale. The cauda epididymis was excised for semen analysis. The testes were preserved in Bouin solution. Longitudinal sectioned testicular tissue specimens were processed for histology studies according to the method described by Bancroft \& Gamble (2008). The tissue specimens were dehydrated with concentrated ethanol, cleared with xylene, and embedded in paraffin wax. Tissue blocks were serially sectioned using a Leica Rotary microtome set at $5 \mu \mathrm{m}$. Testicular tissue sections were stained using Hematoxylin and Eosin stain to assess the general cell architecture of the testicular tissue specimens.

Semen analysis: The cauda epididymis was excised and transferred into normal saline; the spermatozoa were carefully teased out. A drop of normal saline containing spermatozoa was placed on a Neubauer Counting Chamber (hemocytometer) for semen analysis under a light microscope at 10x magnification. Semen analysis and sperm counts were done for each group based on the protocol described in the World Health Organization (WHO) manual (WHO, 2010).

Sperm motility: Sperm motility was assessed using the WHO classification system. Each sample was assessed twice. For consistency, all readings were carried out at $37^{\circ} \mathrm{C}(\mathrm{WHO}, 2010)$. 
Tissue Analysis and photography: Photomicrographs of the stained sections were viewed using an Olympus light microscope (Olympus, Germany) at 400x magnification. Micrograph images were taken with a digital camera (MV500 Cameroscope) attached to the Light Microscope using $10 x$ and $40 x$ objective lenses.

\section{Statistical analysis}

The data obtained were analyzed using Graphpad Prism version 8.4.3 (686) for Windows. The column statistics were used for one-way analysis of variance (ANOVA) and the Tukey post-hoc test for parametric tests. Statistical significance $(*)$ was set at $p<0.05$, i.e., a $p$-value $<0.05$ was considered statistically significant. Data were expressed as Mean \pm Standard deviation (Mean \pm SD). Comparative analysis involving two continuous variables was done using an independent sample t-test, while those involving more than two variables were done using one-way analysis of variance (ANOVA).

\section{RESULTS (Tables 1 and 2)} weight

The effects of Yaji and its constituents on body

This study focused on weight changes in experimental animals given Yaji and its constituents for 28 days ( 4 weeks) and 56 days ( 8 weeks), respectively. There was a significant weight increase $(p<0.05)$ between the initial and final weights of each group (Groups A-G) in the 28 days study. At 28 days, the group given Yaji had a significant increase in body weight (Figure 1) when compared to controls and treated in the groups given cloves and garlic $(p<0.05)$. However, there was no statistically significant increase in body weight when the group given Yaji (B) was compared against the rats fed Red Pepper (C), Black Pepper (D) or Ginger (F) $(p>0.9996)$. In the groups studied for
56 days (Figure 2), a statistically significant increase was seen in the body weights of the rats given Yaji as compared with the groups given black pepper and garlic $(p<0.05)$; no significant weight change was seen when controls $(A)$ and the groups given red pepper (C), cloves (E), or ginger $(F)$ were compared to the groups given Yaji $(B)$, according to the Tukey's multiple comparison test $(p<0.05)$.

\section{Yaji induced an increase in testicular weight}

Testicular weight change was evaluated to vividly describe the effects of Yaji and its spice constituents on testicular tissue mass. In the 28-days study group (Figure $3 \mathrm{~A}$ ), there was a statistically significant increase in testicular. In the 28-day study group (Figure $3 \mathrm{~A}$ ), there was a statistically significant increase in testicular weight in the group given Yaji and red pepper as compared with the controls and treated groups given black pepper, cloves, ginger, and garlic $(p<0.05)$; however, there was no statistically significant difference between the groups given Yaji when compared with the groups administered black pepper (D) or red pepper (C) ( $p>0.05)$. In the 56-days study group, significant increases were seen in the testicular weight of rats given Yaji (B) and red pepper $(p<0.5)$; the difference in testicular weight between the rats given Yaji $(B)$ and red pepper $(C)$ was not statistically significant $(p<0.7453)$.

Yaji and its constituents mediate steroidogenesis via elevated serum testosterone levels

Serum testosterone levels were assayed to determine the integrity of the interstitial cells of Leydig. In this study, serum testosterone levels were studied to evaluate the interplay between Yaji and its isolated spice components on Leydig cell activity concerning testosterone secretion. A significant increase in serum testosterone secretion in Leydig cells was observed in the rats given Yaji in the 28-days study group (Figure 4A) when compared with controls and rats given red

\begin{tabular}{|c|c|c|c|c|c|c|}
\hline Group $(n=5)$ & $\begin{array}{l}\text { Initial Body } \\
\text { weight (g) }\end{array}$ & $\begin{array}{l}\text { Final Body } \\
\text { weight (g) }\end{array}$ & $\begin{array}{l}\text { Testicular } \\
\text { weight }(g)\end{array}$ & $\begin{array}{c}\text { Serum } \\
\text { testosterone } \\
\text { level (ng/dl) }\end{array}$ & $\begin{array}{l}\text { Sperm count } \\
\text { (millions/ml) }\end{array}$ & $\begin{array}{c}\text { Sperm } \\
\text { motility (\%) }\end{array}$ \\
\hline Control (A) & $122 \pm 2.4$ & $163 \pm 5.4$ & $0.93 \pm 0.04$ & $1.5 \pm 0.05$ & $193 \pm 2.2$ & $59 \pm 3.5$ \\
\hline Yaji (B) & $123 \pm 2.9$ & $182 \pm 3.5$ & $1.1 \pm 0.08$ & $2.1 \pm 0.07$ & $216 \pm 5.4$ & $69 \pm 3.7$ \\
\hline Red Pepper (C) & $121 \pm 2.6$ & $181 \pm 6.4$ & $1.1 \pm 0.13$ & $1.9 \pm 0.01$ & $209 \pm 7.8$ & $68 \pm 2.5$ \\
\hline Black Pepper (D) & $123 \pm 5.5$ & $183 \pm 4.7$ & $0.99 \pm 0.03$ & $1.9 \pm 0.05$ & $206 \pm 2.6$ & $68 \pm 3.2$ \\
\hline Cloves (E) & $123 \pm 2.6$ & $166 \pm 7.0$ & $0.94 \pm 0.02$ & $1.9 \pm 0.05$ & $198 \pm 4.7$ & $63 \pm 2.1$ \\
\hline Ginger (F) & $127 \pm 5.6$ & $182 \pm 4.9$ & $0.96 \pm 0.04$ & $1.9 \pm 0.03$ & $196 \pm 3.0$ & $68 \pm 3.0$ \\
\hline Garlic (G) & $126 \pm 2.5$ & $157 \pm 5.6$ & $0.97 \pm 0.03$ & $1.9 \pm 0.02$ & $206 \pm 1.5$ & $67 \pm 2.9$ \\
\hline
\end{tabular}

Table 2. Mean initial and final body weights, testicular weights, serum testosterone levels, and semen analysis of the rats treated for 56 days.

\begin{tabular}{|l|c|c|c|c|c|c|}
\hline Group (n=5) & $\begin{array}{c}\text { Initial Body } \\
\text { weights (g) }\end{array}$ & $\begin{array}{c}\text { Final Body } \\
\text { weights (g) }\end{array}$ & $\begin{array}{c}\text { Testicular } \\
\text { weights (g) }\end{array}$ & $\begin{array}{c}\text { Serum } \\
\text { testosterone } \\
\text { level (ng/d) }\end{array}$ & $\begin{array}{c}\text { Sperm count } \\
\text { (millions/mI) }\end{array}$ & $\begin{array}{c}\text { Sperm } \\
\text { motility (\%) }\end{array}$ \\
\hline Control (A) & $123 \pm 1.1$ & $204 \pm 9.0$ & $0.93 \pm 0.40$ & $1.6 \pm 0.038$ & $223 \pm 1.7$ & $70 \pm 3.7$ \\
\hline Yaji (B) & $128 \pm 1.9$ & $219 \pm 4.1$ & $1.1 \pm 0.11$ & $2.1 \pm 0.14$ & $245 \pm 3.3$ & $76 \pm 4.5$ \\
\hline Red Pepper (C) & $122 \pm 2.1$ & $213 \pm 4.7$ & $1.1 \pm 0.069$ & $2.0 \pm 0.045$ & $233 \pm 1.0$ & $71 \pm 2.7$ \\
\hline Black Pepper (D) & $122 \pm 2.5$ & $203 \pm 3.1$ & $0.98 \pm 0.03$ & $2.1 \pm 0.090$ & $235 \pm 3.8$ & $70 \pm 2.5$ \\
\hline Clove (E) & $124 \pm 2.3$ & $206 \pm 3.0$ & $0.93 \pm 0.03$ & $2.0 \pm 0.037$ & $228 \pm 1.3$ & $70 \pm 4.0$ \\
\hline Ginger (F) & $121 \pm 1.6$ & $204 \pm 4.8$ & $0.92 \pm 0.019$ & $2.0 \pm 0.057$ & $216 \pm 4.2$ & $66 \pm 3.6$ \\
\hline Garlic (G) & $121 \pm 2.6$ & $167 \pm 4.4$ & $0.96 \pm 0.03$ & $2.0 \pm 0.022$ & $235 \pm 8.5$ & $66 \pm 3.1$ \\
\hline
\end{tabular}


Mean Initial body weights ( $g$ ) for 28 days treatment

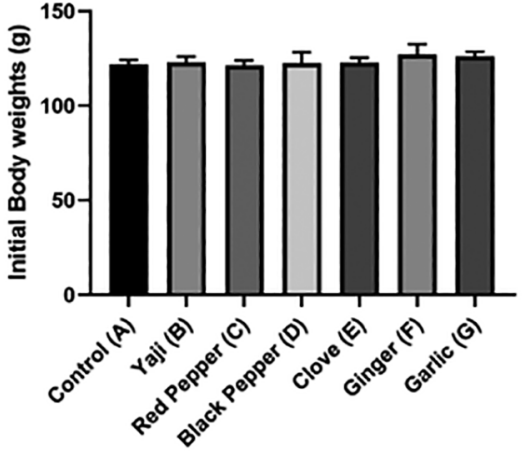

A
Groups ( $n=5)$

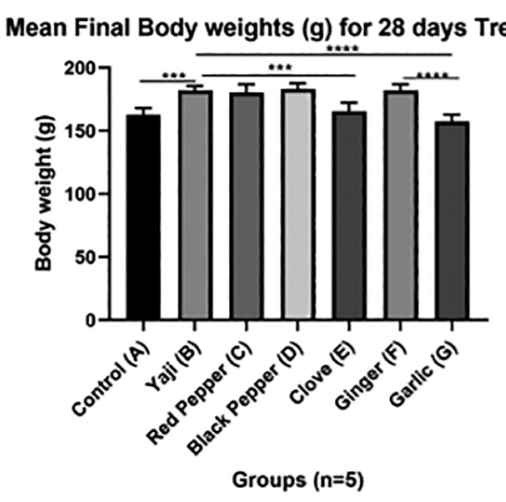

B.

Figure 1. Graphical Representation of Mean Initial and Final Body Weights of Adult Sprague-Dawley rats treated for 28 days. Data analyzed using one-way ANOVA and expressed as Mean \pm Standard Deviation (Mean \pm SD). Statistical Significance is taken at $p<0.05\left(^{*}\right)$ using the Tukey's Post-hoc test. There is a significant difference in the mean final weights at $p<0.05$ in Control (A) vs. Yaji (B) $(* * * p<0.0001)$, Yaji (B) vs. Cloves (E) $(* * * p<0.0010)$; Yaji (B) vs. Garlic (G) $(* * * p<0.0001)$; no significant difference was found in Yaji (B) vs. Red Pepper (C); Yaji (B) vs. Black Pepper (D) or Yaji (B) vs. Ginger (F) (ns: $p>0.9996)$.

Mean Initial Body weight for $\mathbf{5 6}$ days Treatment

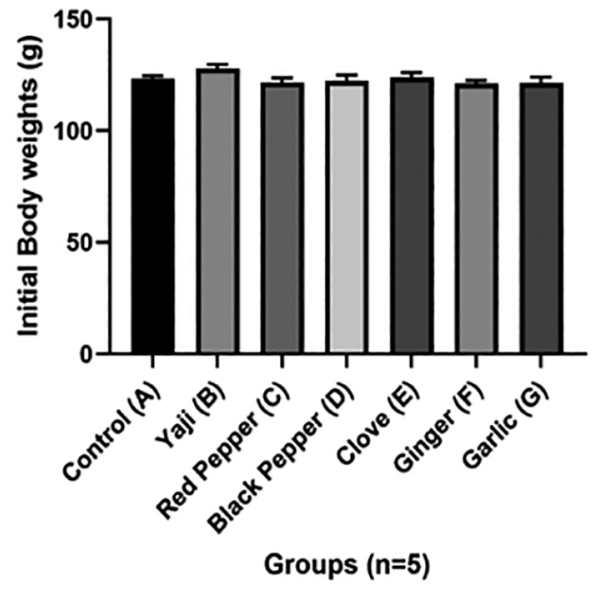

Mean Final Body weight for $\mathbf{5 6}$ days Treatment

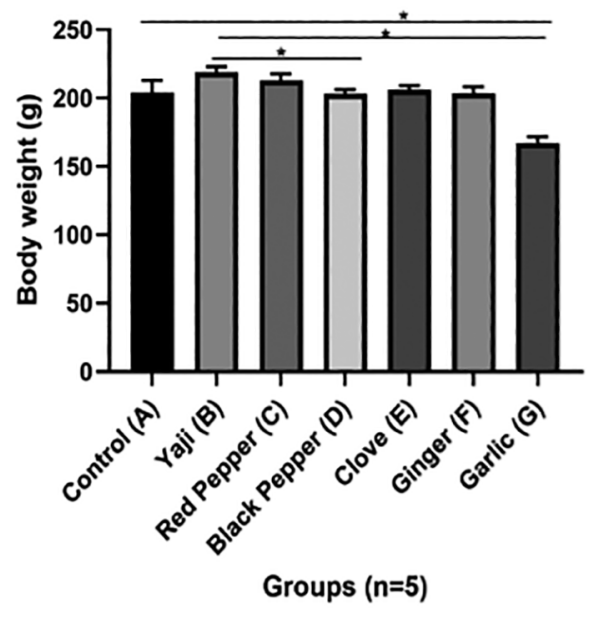

B.

Figure 2. Graphical Representation of Mean Initial and Final Body Weights of Adult Sprague-Dawley rats treated for 56 days. Data analyzed using one-way ANOVA and expressed as Mean \pm Standard Deviation (Mean \pm SD). Statistical Significance is taken at $p<0.05\left(^{*}\right)$ using the Tukey's Post-hoc test. There is a significant difference in mean final weight at $p<0.05$ for Yaji (B) vs. Black Pepper (D) $(* * p=0.0091)$ and Yaji (B) vs. Garlic (G) $(* * * * p<0.0001)$; no statistical difference was found in Control (A) vs. Yaji (B); Yaji (B) vs. Red Pepper (C); Yaji (B) vs. Cloves (E); or Yaji (B) vs. Ginger (F) using Tukey's multiple comparisons tests.

pepper, garlic, black pepper, clove, or ginger. In the 56-day study group (Figure 4B), Yaji caused a significant increase in serum testosterone levels as compared with controls; no significant difference was seen in the comparison performed with rats given Red Pepper (C), Black Pepper (D), Ginger (F), Garlic (G) or Cloves (E) $(p<0.05)$.

Yaji and its constituents improved sperm count

Sperm count (SC) evaluation is used as an index to measure fertility or the fertility potential of a therapy. In the 28-days study group (Figure 5A), there was an increase in the sperm count of rats given Yaji Yaji when compared with the control and rats given black pepper, ginger, clove, red pepper, or garlic. Significant increases were also seen when rats given red pepper, black pepper, garlic, cloves, and ginger were compared with the control group. There was no statistical difference in the group given Yaji (B) when compared with the groups given red pepper (C) or garlic (G). The rats given Yaji for 56 days (Figure 5B) had a significant increase in sperm count. The rats treated with ginger had significant decrease in sperm count $(p<0.05)$. There was no statistically significant difference in sperm count of the control $(A)$, rats given cloves $(E)$, red pepper $(C)$, or garlic $(G)$ were compared to the rats given Yaji (B). 
Mean Testicular weight $(\mathrm{g})$ for 28 days treatment

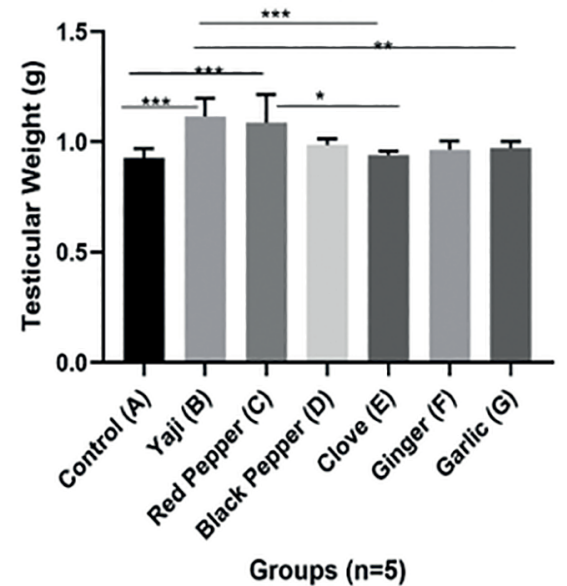

A

Figure 3. Graphical Representation of Mean Testicular weight of Adult Sprague-Dawley rats treated for 28 and 56 days. Data analyzed using one-way ANOVA and expressed as Mean \pm Standard Deviation (Mean \pm SD). In the group treated for 28 days (Figure $3 \mathrm{~A}$ ), we observed a significant difference at $p<0.05$ for Control (A) vs. Yaji (B) $(* * p=0.0015)$, Yaji (B) vs. Cloves (E) $(* * p=0.0037)$, Yaji (B) vs. Ginger (F) $(* p=0.0160)$, and Yaji (B) vs. Garlic $(\mathrm{G})(* p=0.0228)$. No significant difference was found in Yaji (B) vs. Black Pepper (D) or Yaji (B) vs. Red Pepper (C) $(p>0.05)$. In the group treated for 56 days (Figure 3B), significant differences were found in Control (A) vs. Yaji (B) $(* * * * p<0.0001)$, Yaji (B) vs. Cloves $(E)(* * * * p<0.0001)$, Yaji (B) vs. Ginger (F) $(* * * * p<0.0001)$, and Yaji (B) vs. Garlic $(\mathrm{G})(* * * p=0.0004)$; no statistical difference was found in Yaji (B) vs. Red Pepper (C) (ns: $p=0.7453$ ).

Mean Serum Testosterone Level for 28 days treatment

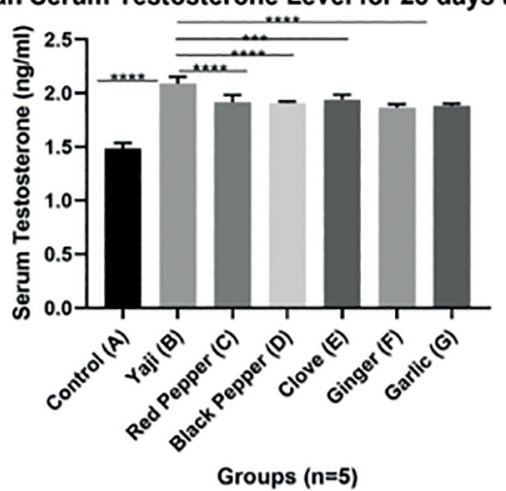

A

Groups ( $n=5)$
Figure 4. Graphical Representation of Mean Serum testosterone level $(\mathrm{mg} / \mathrm{ml})$ of Adult Sprague-Dawley rats treated for 28 and 56 days. Data analyzed using one-way ANOVA and expressed as Mean \pm Standard Deviation (Mean $\pm S D$ ). In the group treated for 28 days (Figure 4A), we observed a significant difference in Control (A) vs. Yaji (B) $(* * * * p<0.0001)$, Yaji (B) vs. Red Pepper (C) $(* * * * p<0.0001)$, Yaji (B) vs. Black Pepper (D), $(* * * * p<0.0001)$, Yaji (B) vs. Ginger (F), Yaji (B) vs. Garlic (G) $(* * * * p<0.0001)$, and Yaji (B) vs. Cloves $(E)(* * * p=0.0004)$; in the group treated for 56 days (Figure 4B), a significant difference was found in Control (A) vs. Yaji $(B),(* * p=0.0063)$; no significant difference was found in Yaji (B) vs. Red Pepper (C), Yaji (B) vs. Black Pepper (D), Yaji (B) vs. Ginger (F), Yaji (B) vs. Garlic (G), or Yaji (B) vs. Cloves (E). were compared to animals administered red pepper (C) or garlic $(G)(p<0.05)$. The rats treated with Yaji $(B)$ for 56 days (Figure 6B) had a significant increase in sperm motility when compared to rats given ginger $(F)$ $(* p<0.0211)$; no statistical difference was seen when rats given Yaji $(B)$ were compared with control $(A)$, rats given red pepper $(C)$, black pepper $(D)$, cloves $(E)$ or garlic $(G)(p<0.05)$. en cloves $(E)$, and ginger $(F)(* p<0.00056)$; no statistical difference was observed when rats given Yaji (B)
Mean Serum Testosterone Level for 56 days treatment

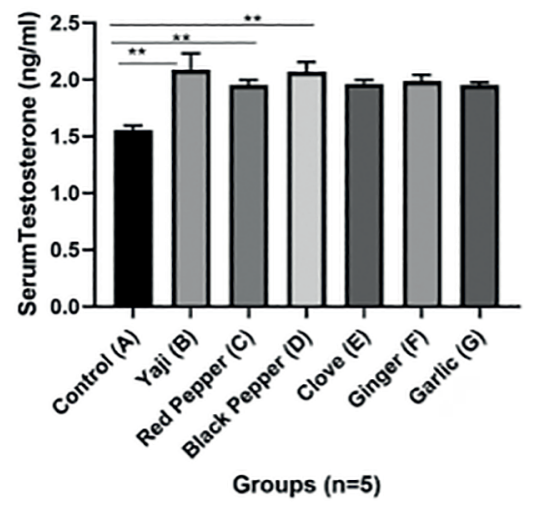

Yaji and its constituents increased the numbe

Sperm motility is used to evaluate the strength or viability of spermatozoa. A significant increase in sperm motility was seen in the 28-days study group (Figure )

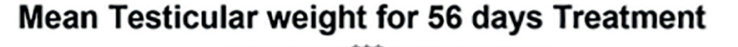

Mean Testicular weight for 56 days Treatment 
Mean Sperm Count 28 days treatment

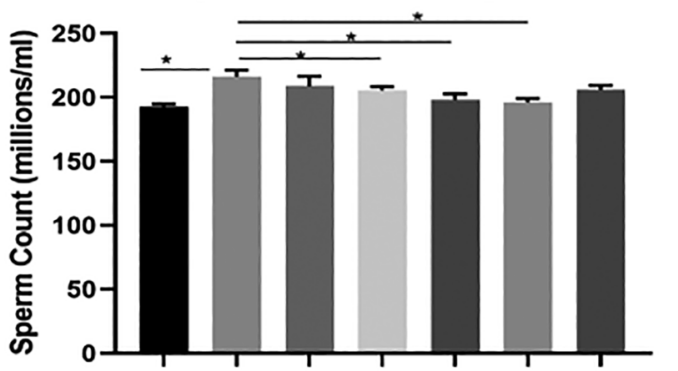

A

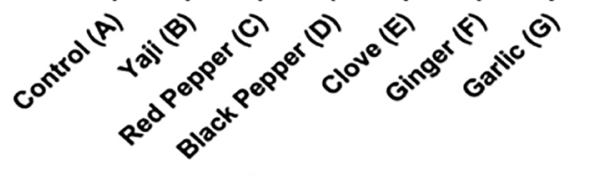

Groups $(n=5)$
Mean Sperm Count 56 days Treatment

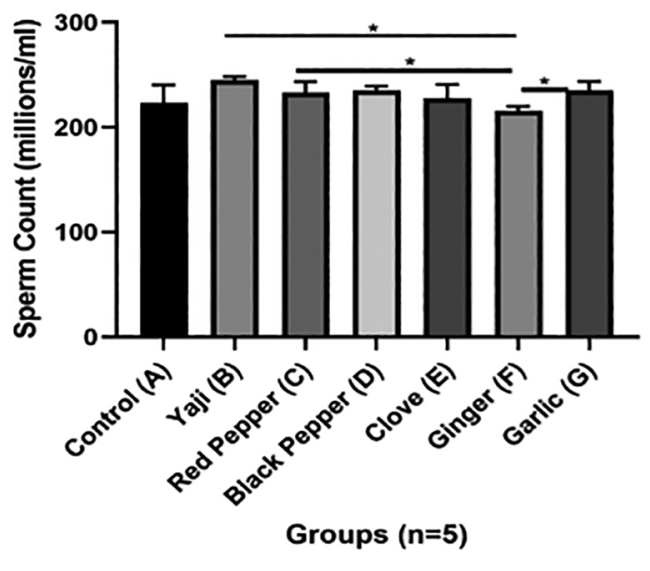

Figure 5. Graphical Representation of Mean Sperm count (millions/ml) of Adult Sprague-Dawley rats treated for 28 and 56 days. Data analyszd using one-way ANOVA and expressed as Mean \pm Standard Deviation (Mean \pm SD). In the group treated for 28 days (Figure $5 A$ ), we observed a significant difference in Control (A) vs. Yaji (B), (** $p=0.0013)$, Yaji (B) vs. Black Pepper (D) $(* p=0.0100)$, Yaji (B) vs. Ginger (F) $(* p=0.0448)$, and Yaji $(B) v s$. Cloves $(E)(* p=0.0396)$; no significant difference was seen in Yaji (B) vs. Red Pepper (C) or Yaji (B) vs. Garlic (G). In the group treated for 56 days (Figure 5B), we found a significant difference in Yaji $(B)$ vs. Ginger $(F)(* p=0.00056)$; no significant difference was seen in Control (A) vs. Yaji (B), Yaji (B) vs. Cloves (E), Yaji (B) vs. Red Pepper (C) or Yaji (B) vs. Garlic (G).

A

Mean Sperm Motility for 28 days treatment

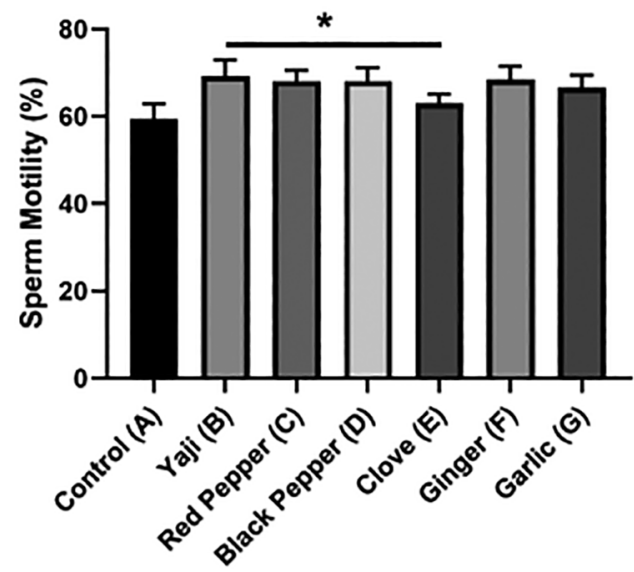

Groups ( $n=5)$
Mean Sperm Motility for 56 days Treatment

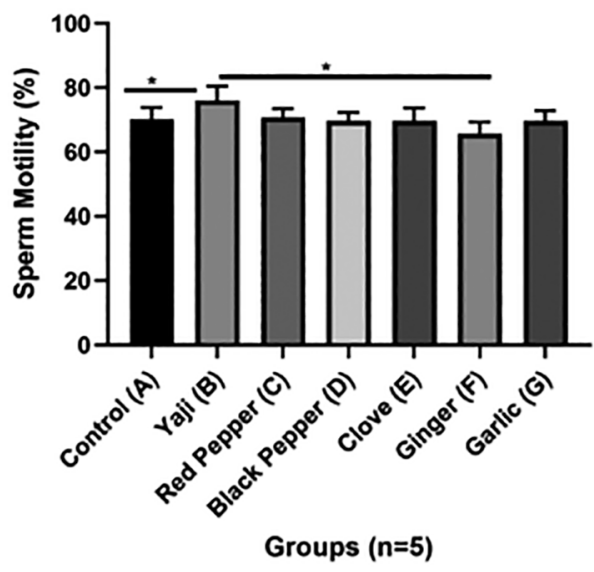

Figure 6. Graphical Representation of Mean Sperm motility (\%) of Adult Sprague-Dawley rats treated for 28 and 56 days. Data analyzed using one-way ANOVA and expressed as Mean \pm Standard Deviation (Mean \pm SD). In the group treated for 28 days (Figure $6 A$ ), we observed a significant difference in Control (A) vs. Yaji (B), Yaji (B) vs. Ginger (F) (*p=0.00056), Yaji (B) vs. Red Pepper (C) and Yaji (B) vs. Garlic (G) are not significant at $p<0.05$ but Yaji $(B)$ vs. Clove (E) $(* p=0.0433)$ was significant. In the group treated for 56 days (Figure $6 B)$, a significant difference was seen in Yaji $(B)$ vs. Ginger $(F)(* p=0.0211)$; no statistical difference was seen in Control (A) vs. Yaji (B), Yaji (B) vs. Red Pepper (C), Yaji (B) vs. Black pepper (D), Yaji (B) vs. Cloves (E) or Yaji (B) vs. Garlic (G).

Yaji and its spice constituents influence spermatogenesis and Leydig Cell proliferation

Hematoxylin and Eosin (H\&E) staining was used to demonstrate testicular cells inclusive of spermatogenic cell series and Leydig cells. The micrographs are displayed in 100x (Figures 7A and $8 \mathrm{~A}$ ) and 400x magnification (Figures $7 B$ and $8 B$ ). The control group showed the presence of all spermatogenic cell series, interstitial cells of Leydig, and less occluded seminiferous tubule lumens with no disruption of the spermatogenic cell lineage. The groups given Yaji (B), red pepper (C), black pepper (D), clove (E), and ginger (F) for 28 days (Figure 7 ) showed mild histological disruption of the spermatogenic cell series as compared to control and rats given garlic. However, the interstitial cells were not disrupted. In the group treated for 56 days (Figures $8 \mathrm{~A}$ and $\mathrm{B})$, control $(\mathrm{A})$ had presence of proliferative 

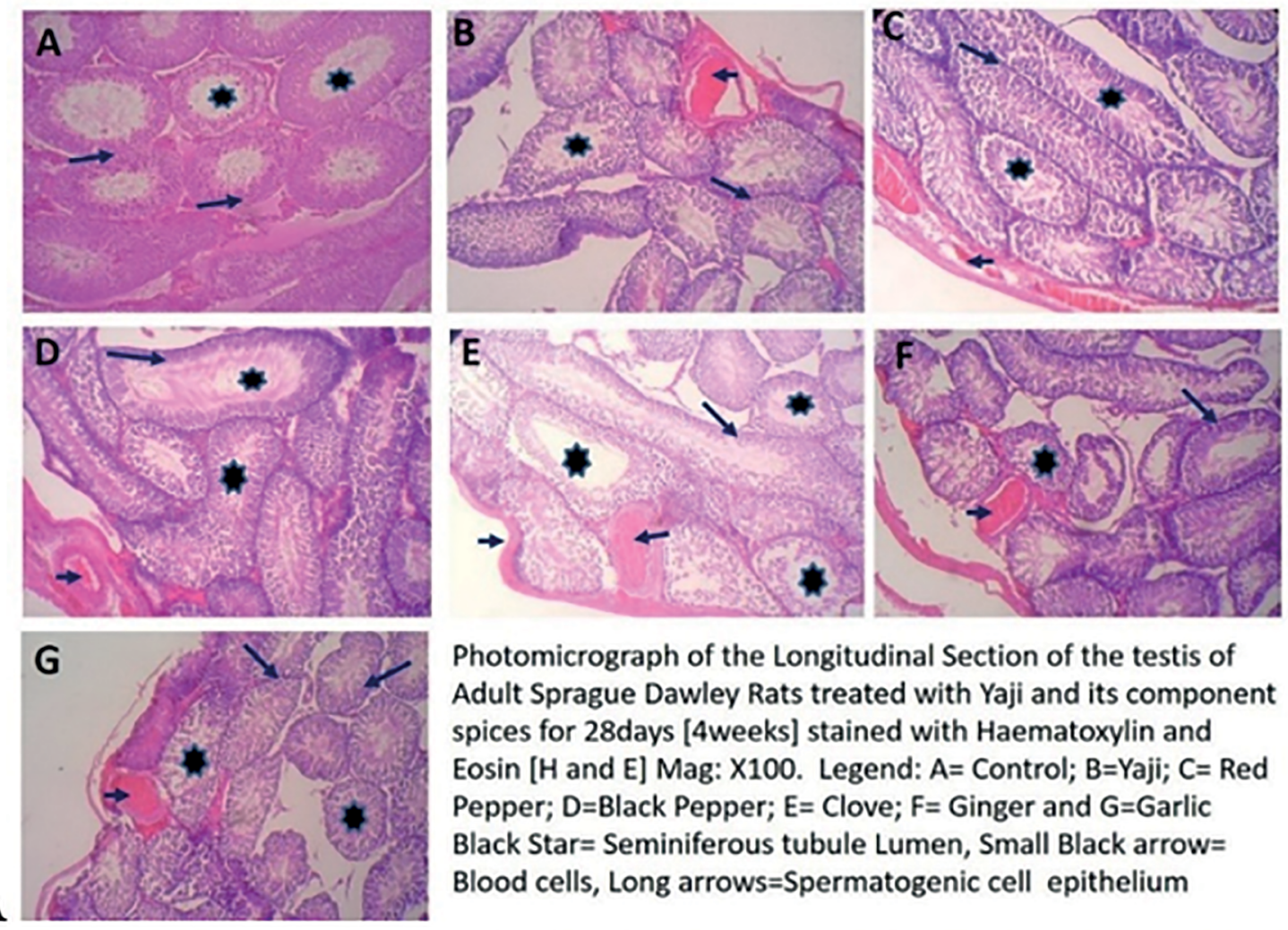

Photomicrograph of the Longitudinal Section of the testis of Adult Sprague Dawley Rats treated with Yaji and its component spices for 28days [4weeks] stained with Haematoxylin and Eosin [ $\mathrm{H}$ and $\mathrm{E}$ ] Mag: $\mathrm{X} 100$. Legend: $\mathrm{A}=$ Control; $\mathrm{B}=\mathrm{Yaji} ; \mathrm{C}=$ Red Pepper; $\mathrm{D}=\mathrm{Black}$ Pepper; $\mathrm{E}=$ Clove; $\mathrm{F}=\mathrm{Ginger}$ and $\mathrm{G}=\mathrm{Garlic}$ Black Star= Seminiferous tubule Lumen, Small Black arrow= Blood cells, Long arrows=Spermatogenic cell epithelium
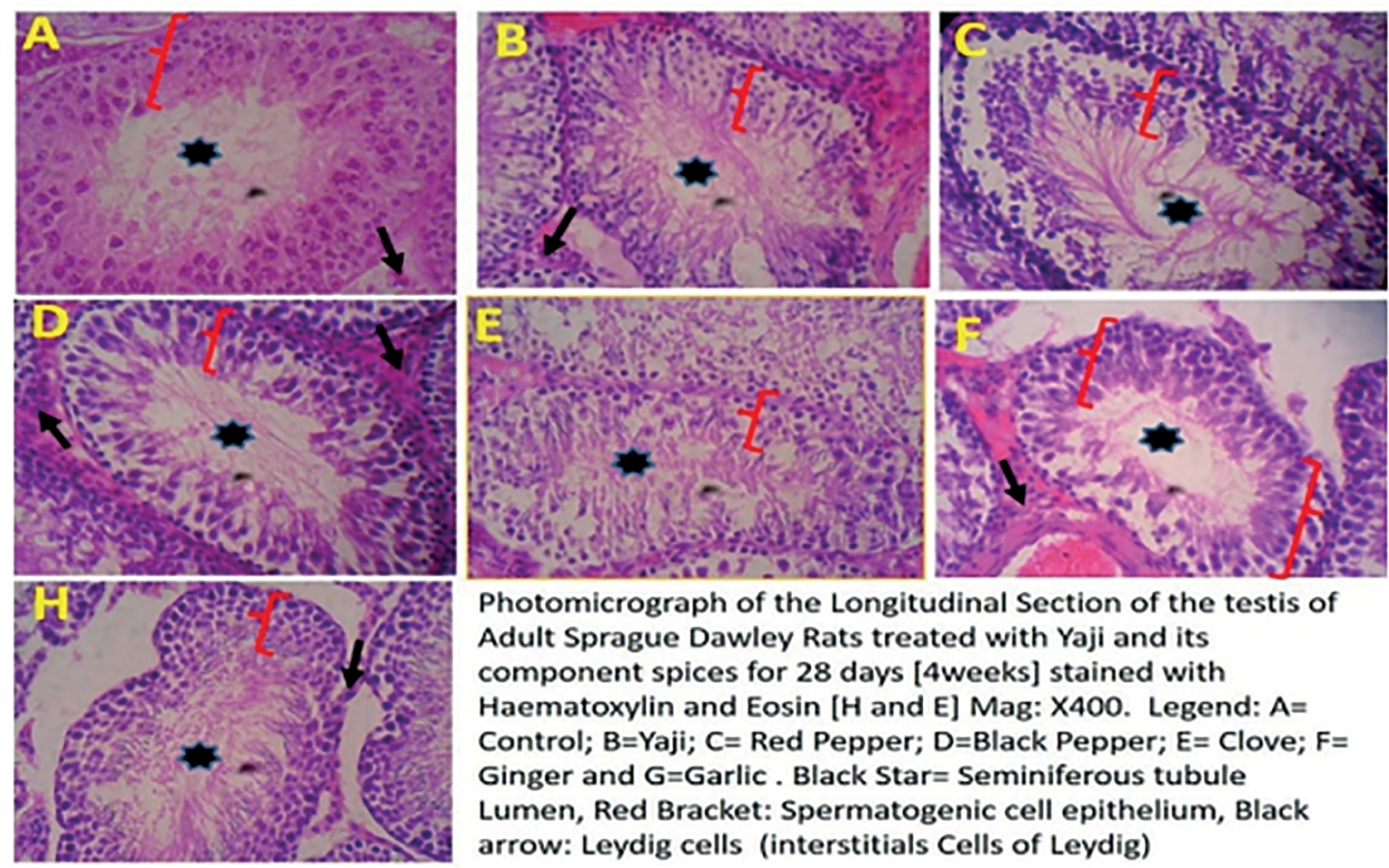

Photomicrograph of the Longitudinal Section of the testis of Adult Sprague Dawley Rats treated with Yaji and its component spices for $\mathbf{2 8}$ days [4weeks] stained with Haematoxylin and Eosin $[H$ and $E]$ Mag: $X 400$. Legend: $A=$ Control; B=Yaji; C= Red Pepper; D=Black Pepper; $\mathrm{E}=$ Clove; F= Ginger and $\mathrm{G}=$ Garlic . Black Star $=$ Seminiferous tubule Lumen, Red Bracket: Spermatogenic cell epithelium, Black $\mathrm{B}$ arrow: Leydig cells (interstitials Cells of Leydig)

Figure 7. Photomicrograph of a section of the longitudinal section of the testes of Adult Sprague-Dawley rats treated for 28 days. H\&E stain captured at 10x (Figure 7A) and 40x (Figure 7B) magnification. Legend: $\mathrm{A}=$ Control, $\mathrm{B}=$ Yaji, $\mathrm{C}=$ Red pepper, $\mathrm{D}=\mathrm{Black}$ pepper, $\mathrm{E}=$ Cloves, $\mathrm{F}=$ Ginger, and $\mathrm{G}=\mathrm{Garlic}$. Black arrows=Leydig cells (Interstitial cells); black asterisk=seminiferous tubule lumen and red bracket: basal and adluminal membrane of the seminiferous tubule made up of spermatogenic cell lineage. The control group had all spermatogenic cell series, interstitial cells of Leydig and less occluded seminiferous tubule lumen. Rats given Yaji, red pepper, black pepper, cloves, and ginger had mild histological disruptions of the spermatogenic cell series as compared to controls and rats given garlic. However, the interstitial cells were undisrupted. 

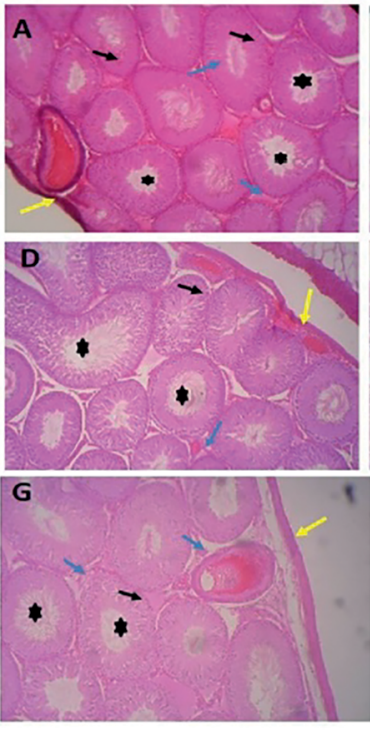
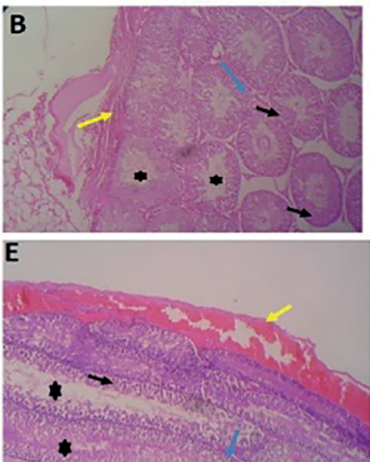

Photomicrograph of the Longitudinal Section of the testis of Adult Sprague Dawley Rats treated with Yaji and its component spices for 56 days [8weeks] stained with Haematoxylin and Eosin [H and E] Mag: X100. Legend: $A=$ Control; $\mathrm{B}=$ Yaji; $\mathrm{C}=$ Red Pepper; $\mathrm{D}=\mathrm{Black}$ Pepper; $\mathrm{E}=$ Clove; $\mathrm{F}=$ Ginger and $G=$ Garlic Black Star= Seminiferous tubule Lumen, black arrows $=$ Spermatogenic cell epithelium, blue arrows $=$ Leydig Cells and yellow arrows $=$ Tunica Albuginea
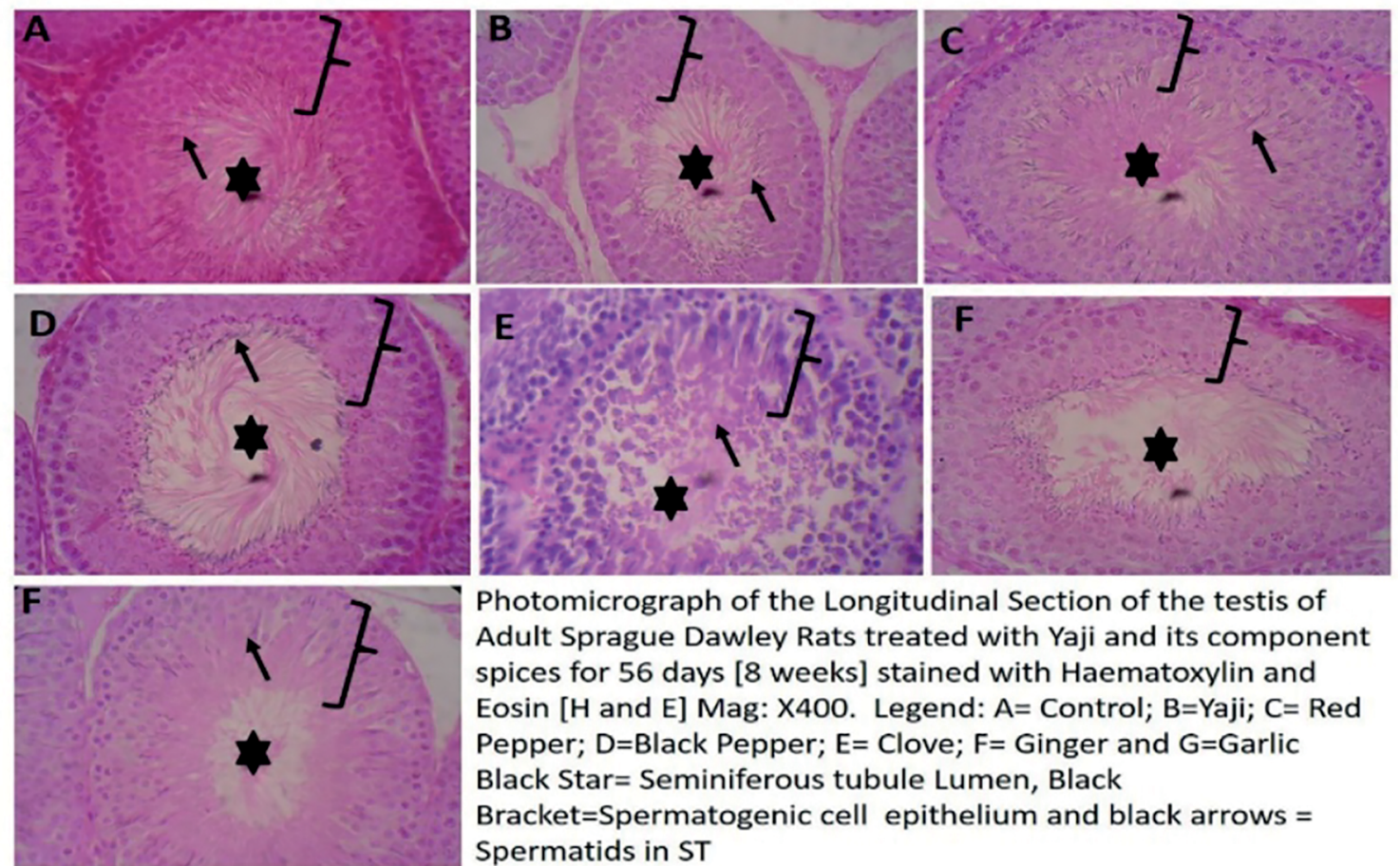

Photomicrograph of the Longitudinal Section of the testis of Adult Sprague Dawley Rats treated with Yaji and its component spices for 56 days [ 8 weeks] stained with Haematoxylin and Eosin [H and E] Mag: X400. Legend: $\mathrm{A}=$ Control; $\mathrm{B}=\mathrm{Yaji} ; \mathrm{C}=\mathrm{Red}$ Pepper; $\mathrm{D}=$ Black Pepper; $\mathrm{E}=$ Clove; $\mathrm{F}=$ Ginger and $\mathrm{G}=\mathrm{G}$ arlic Black Star= Seminiferous tubule Lumen, Black Bracket $=$ Spermatogenic cell epithelium and black arrows $=$ Spermatids in ST

Figure 8. Photomicrograph of a section of the longitudinal section of the testes of Adult Sprague-Dawley rats treated for 28 days. H\&E stain captured at 10x (Figure 8A) and 40x (Figure 8B) magnification. Legend: $\mathrm{A}=$ Control, $\mathrm{B}=$ Yaji, $\mathrm{C}=$ Red pepper, $\mathrm{D}=$ Black pepper, $\mathrm{E}=$ Cloves, $\mathrm{F}=$ Ginger, and $\mathrm{G}=$ Garlic. Yellow arrows=Tunica vaculosa, Blue arrows=Leydig cells (Interstitial cells); black asterisk=seminiferous tubule lumen, Black arrows=spermatogenic cells, and Black bracket: basal and adluminal membrane of the seminiferous tubule made up of the spermatogenic cell lineage. Controls had all spermatogenic cell series, spermatids in the adluminal compartment, proliferative interstitial cells of Leydig, and waves of spermatids in the seminiferous lumen. Similar histological features were observed in rats given Yaji, red pepper, black pepper, and ginger. The group given cloves had disruptions of spermatogenic cells series in the adluminal compartment as compared to the basal compartment of the seminiferous tubule. However, the interstitial cells were undisrupted in all study groups treated for 56 days. 
interstitial cells of Leydig, well-aligned spermatogenic cell series in contact with the basement membrane, and brush-like waves of spermatids in the seminiferous tubule ad luminal junction and its lumen, in addition to waves of spermatids in the ST lumen. These histological findings were also seen in the groups given Yaji, red pepper, black pepper, and ginger. However, the rats given cloves showed disruption of spermatogenic cells series in the ad luminal compartment as compared to the basal compartment of the seminiferous tubule. However, the interstitial cells were undisrupted in all study groups treated for 56 days.

\section{DISCUSSION}

The diets and food supplements available globally give ample opportunity to procure and provide intervention, considering therapeutics and supplements for fertility problems (Sinclair, 2000; Cheah \& Yang, 2011; Robbins et al., 2012). These food, herbs, or spices are consumed in mixtures featuring other spices or herbs (Rahmawati \& Bachri, 2012). The foods and diets that show promise at improving male fertility possess micronutrients, such as folic acid, selenium, zinc, and vitamins $C$ and $E$, with the ability to improve sperm quality. Other foods, if consumed in excess and even in minute quantities, may disrupt sperm integrity (Eslamian et al., 2012).

Mostly, men consume Yaji hence this study was designed to evaluate whether there is a synergistic effect derived from the consumption of the mixture of spices present in Yaji upon male fertility and describe its mechanism, in a bid to demonstrate its effects on male reproductive and nutritional health awareness.

This study showed that Yaji caused a significant increase in body weight in the rats treated for 28 and 56 days when comparisons were made between rats given Yaji and subjects in the control, clove, garlic, red pepper, ginger, and black pepper groups. This implies Yaji has anabolic potentials. According to Agbo et al. (2013), Yaji caused a dose-dependent increase in body weight, i.e., the dose of Yaji was directly proportional to weight gain. This elevated weight of rats given Yaji is contrary to what Akpamu et al. (2011b) found; in their study, $9 \mathrm{~g}$ of Yaji caused a significant reduction in body weight as compared with rats given cloves, ginger, red pepper, black pepper, and groundnut. Ukoha et al. (2014) reported that Yaji caused a dose-dependent body weight loss, contrary to observations in our study. The increase in body weight seen in our study might be linked to the dose of Yaji administered. Its constituent spices - Red Pepper, Black pepper, Cloves, and Ginger - caused an increase in body weight, as reported by Mbongue et al. (2005), Hassan et al. (2010), and Akpamu et al. (2011a). Black pepper as an ingredient that increases body weight and induces increased eating contradicts reports by Vijayakumar et al. (2004), in which it was described as a lipid-lowering spice. Garlic caused a significant decrease in body weight gain in our study on account of its potential in altering body fat deposition, adipose tissue weight, serum lipid profiles, and regulating lipid metabolism, coupled with its active compound allicin potential to mediate cascade reactions involved in the reduction of visceral fat gain in rats, thereby increasing its effectiveness at lowering weight gain and triglycerides levels (Memudu et al., 2015; Yang et al., 2018; Quesada et al., 2020) via an increase in fat metabolism. Ginger caused an elevation in body weight, a finding contrary to its described weight reducing potential documented by Micheal et al. (2008). Rats given cloves had significant decreases in body weight, as reported by Agbaje et al. (2009). Red pepper induced body weight gain in our study, contrary to reports made by Erdost et al. (2009), in which a diet containing $1 \%$ red hot pepper (10 g/ kg diet) caused decreases in body weight. It was deduced from our study that Yaji potentiates increase in body weight due to constituents such as Red Pepper, Black pepper, Cloves, and Ginger. These spices have anabolic and androgenic potentials linked with an increasing eating patterns linked to increase in body weight.

The evaluation of the changes in organ weight is an indicator to ascertain whether a tested substance or drug is toxic or therapeutic (Nirogi et al., 2014). A significant decline or increase in the absolute or relative weight of an organ after administration of a drug/supplement indicates the toxicity of that particular drug or substance (Maina et al., 2008; Simmons et al., 1995). Testicular weight change was evaluated to vividly describe the effects of Yaji and its spice constituents on testicular tissue mass. In regard to testicular weight, Ogwo et al. (2016) mentioned that declines in testicular weight might be attributed to falling testosterone levels, as testosterone plays a role in the enhancement of testicular growth; therefore, severe declines in testosterone concentration may cause testicular atrophy. Furthermore, the weight of the reproductive organs always gives a good measure of the degree of spermatogenesis in rats (Raji et al., 2005). In the 28- and 56-days study group, the rats treated with Yaji and red pepper had increases in testicular weight as compared with the control and rats given cloves, ginger, and garlic $(p<0.05)$; however, no significant difference was seen between the rats given Yaji (B) and the groups treated with Black Pepper (D) and Red Pepper (C). The observed increase in testicular weight in the groups given Yaji, Red pepper, and Black Pepper as compared with other study groups was accompanied by increases in body weight due to fat deposition and proliferative testicular tissue cells as observed in testicular histology tests. The higher testicular weight seen in the rats given these spices supports reports made by Agrawal \& Bhide (1987) and Final report on the safety assessment of capsicum annuum extract, capsicum annuum fruit extract, capsicum annuum resin, capsicum annuum fruit powder, capsicum frutescens fruit, capsicum frutescens fruit extract, capsicum frutescens resin, and capsaicin (2007). Hence, there was an appreciable degree of spermatogenesis progress in the testes (Raji et al., 2005). Contrary to Ukoha et al. (2014), in our study Yaji caused increases in testicular weight. This is probably linked to a lower dose of $200 \mathrm{mg}$ in our study versus the 5 to $15 \mathrm{~g}$ used by Ukoha et al. (2014). Black pepper and its active compound piperine may potentiate a significant reduction in testicular weight (Chinta et al., 2017), but this was not evident in our study. Some studies linked a reduction in testicular weight in rats to decreases in their testosterone levels (Nirogi et al., 2014), since testosterone plays a role in the enhancement of testicular growth; hence, a marked decline in its concentration might cause testicular atrophy (Ogwo et al., 2016).

Serum testosterone levels were assayed to determine the integrity of the interstitial cells of Leydig, since testosterone, a hormone responsible for male sexual libido, is secreted by Leydig cells (Wallen, 2001). In our study, serum testosterone levels were studied to evaluate the interplay 
between Yaji and its isolated spice components on Leydig cells proliferative and secretory activity. The group given Yaji for 28 days had a significant increase in serum testosterone secretion by Leydig cells when compared with the control group and the rats given red pepper, garlic, black pepper, cloves, and ginger; however, there was no significant difference between the rats given Yaji and Red Pepper (C), Black Pepper (D), Ginger (F), Garlic (G) and Cloves (E) treated for 56 days. This shows that there is a correlation between Yaji and the steroidogenic process involving testosterone production in the Leydig cells (Kochhar, 2008; Memudu et al., 2015). Black pepper, red pepper, and Ginger induced steroidogenesis possibly via their high contents of fatty acids (Meghwal \& Goswami, 2012), including auric acid, myristic acid, and palmitic acid, all required in androgen synthesis (Gromadzka-Ostrowska, 2006). It is worth noting that piperine in black pepper may reportedly cause significant decreases in the weight of the testes, an event attributed to a histological regression in the seminiferous tubule cell mass resulting from cell death or disruption of the spermatogenic cell series, subsequently leading to spermatogenesis arrest and impaired testosterone synthesis by Leydig cells (Ukoha et al., 2014). Piperine's alleged potential to damage the epididymal environment and sperm function occurs via increases in reactive oxygen species levels, which thus lower the activity of antioxidant enzymes in the epididymis ( $D^{\prime} \mathrm{Cruz}$ \& Mathur, 2005; Mishra \& Singh, 2009). Nevertheless, reports have often described a biological role for piperine as an antioxidant, anticancer, antipyretic, anti-inflammatory (Ahmad et al., 2012) agent, shedding light on the conflicting scientific reports on black pepper and its active compound piperine. This study showed a direct proportional increases in testicular weight and serum testosterone levels in rats given cloves, Yaji, red pepper, and black pepper, contrary to Ukoha et al. (2014) but corroborated by reports made by Nirogi et al. (2014), Ogwo et al. (2016) and Orieke et al. (2019), in which testicular weight changes were directly proportional to testosterone levels, a reflection of the role testosterone has in testicular growth. Semen analysis is used as input in investigations about infertility potentially caused by drugs and supplements, since it is a measure of male fertility in clinical and basic andrology (Vasan, 2011). Routine semen analysis provides basic, useful health information concerning sperm production, sperm count, sperm motility, and viability (Jequier, 2010; Vasan, 2011) that may be used in research and studies on fertility potential. Male infertility is linked to a decline in semen quality (Abarikwu, 2013). Infertility may be caused due to low sperm count, impaired sperm motility, decreased testosterone levels, and abnormal sperm morphology (Kumar \& Singh, 2015). Our study used sperm count (SC) as an index to measure the fertility potential of Yaji and its constituent spices (Guzick et al., 2001). As mentioned earlier, Yaji is mostly consumed by male folk in Nigeria. Reports have shown that diet is a contributing factor to the male infertility index (Jahan et al., 2009). In this study, Yaji caused an increase in the sperm counts of rats treated for 28 and 56 days.

The mammalian epididymis plays a significant role in the functional maturation of spermatozoa due to its ability to secrete an optimal level of sialic acid, an essential element in spermatozoa functional integrity (Prasad \& Rajalakshmi, 1976; Rajalakshmi, 1992). Hence, Yaji probably induced spermatogenesis and improved the epididymal environment for sperm maturation and function by lowering reactive oxygen species levels as a result of its spices mixture potential to increase the activity of antioxidant enzymes in the epididymis. The antioxidant properties present in its spices protect spermatozoa from oxidative stress during sperm development (Maneesh et al., 2005), thus increasing the number of spermatocytes. Our study showed that Yaji's spice components red pepper, black pepper, garlic, cloves, and ginger significantly increased the sperm counts of treated rats as compared with the control group. However, there was no statistically significant change in the sperm counts when rats given Yaji were compared with the control $(A)$ and the rats given cloves $(E)$, red pepper $(C)$, or garlic (G). This study assessed sperm motility as an indicator for spermatozoa strength or viability. In the groups treated for 28 and 56 days, Yaji caused a statistically significant increase in sperm motility as compared with controls and rats given cloves $(E)$ and ginger $(F)$. No significant difference was found when rats given Yaji (B) were compared with their counterparts given red pepper $(C)$, black pepper (D), cloves (E), or garlic (G). This suggests that all the active compounds in Yaji work in synergy to improve semen quality. However, contrary to reports by Hammami et al. (2008; 2009), in which garlic was described to mediate decreases in serum testosterone levels and to cause degenerative changes in testicular histology, our findings indicated that garlic induces serum testosterone level increases. Cloves reportedly increase sperm count, motility, and viability (Mishra \& Singh, 2009). Garlic (Memudu et al., 2015), red pepper (Babaei Garmkhany \& Yousofvand, 2015) and black pepper (Sutyarso et al., 2015; Zodape \& Gaikwad, 2019) have also been reported to improve sperm count and motility due to their androgenic and antioxidant properties. Hence, their interplay caused an elevation in sperm count and motility in rats given Yaji, contrary to reports made by Ukoha et al. (2014) that Yaji might impair testicular function. The observed increases in testosterone levels imply functional, secreting Leydig cells and pro-fertility effects (Okereke \& Onuoha, 2015) of Yaji, red pepper, black pepper, ginger, and cloves.

The testis is a male reproductive organ involved in spermatogenesis in the seminiferous tubules and steroidogenesis (testosterone synthesis) in the interstitial cells of Leydig (Payne \& O'Shaughnessy, 1996; Ogbuewu et al., 2011; Sembulingam \& Prema, 2016). In the testes, spermatogenic cells are formed in the seminiferous tubules, and atrophy in this tubule results in disturbed spermatogenesis (Ahmed-Farid et al., 2017), decreased spermatids leading to declines in fertility and decreased reproductive performance (Cheah \& Yang, 2011; Ahmed-Farid et al., 2017). Hematoxylin and Eosin (H\&E) stain has been used to demonstrate testicular cells inclusive of spermatogenic cell series and Leydig cells (Chinta et al., 2017). Histopathology tests performed in the testicular tissue of the rats treated for 28 days using $H \& E$ stain revealed the presence of all spermatogenic cell series, interstitial cells of Leydig, and less occluded seminiferous tubule lumen with no disruption of the spermatogenic lineage in the control. However, the groups given Yaji (B), red pepper (C), black pepper (D), cloves (E), and ginger $(F)$ for 28 days (Figures 7A and 7B) showed mild histological disruption of the spermatogenic cell series as compared with controls and rats given garlic, although interstitial cells of Leydig were not disrupted. The micrographs of the specimens taken from the rats treated for 56 days (Figures $8 A$ \& $8 \mathrm{~B})$ revealed spermatids in the adluminal compartment of the seminiferous tubules in comparison with the rats treated for 28 days, in addition to proliferative interstitial cells of Leydig, and well-aligned spermatogenic cell series in contact with the basement membrane. The rats given Yaji, red pepper, black pepper, and ginger showed similar histological features, including brush-like waves of spermatids in the seminiferous tubule adluminal compartment, presence of Type $A$ and $B$ spermatogonia in the basal membrane of the seminiferous tubules, primary spermatocytes, and distinguishable spermatids. 
This study showed that Yaji improved spermatogenesis, supports seminiferous tubule cells and Leydig cell proliferation, by means of synergistic reactions between spice constituents. This phenomenon is best explained based on Yaji's ability to stimulate the production of testosterone from Leydig cells in the testis as reported in this study to support male reproductive function. Testosterone promotes the development of reproductive organs (Sembulingam \& Prema, 2016). The observed increase in testosterone levels may have resulted from either the direct effect of Yaji and its spices on the proliferation and secretory activity of Leydig cells or the indirect effects arising from the increasing activity of luteinizing hormone level (Okereke \& Onuoha, 2015). Medicinal plants, their flavonoids and antioxidant components have been used in the treatment of reproductive system disorders (Hosseini, 2018). Plants with high antioxidant potential protect the testicular milieu from reactive oxygen species (ROS). Ginger's antioxidant and pro-spermatogenic activity have been documented by (Ugbogu et al., 2018). Antioxidant properties (Viuda-Martos et al., 2010) have been described for eugenol - an active constituent of cloves (Jaganathan \& Supriyanto, 2012; Kabuto et al., 2007; Scherer et al., 2009). Red pepper extracts showed strong antioxidant activity (Sim \& Sil, 2008; Ademoyegun et al., 2011). Red pepper reportedly enhanced the proliferation of Leydig cells that secrete testosterone and are involved in spermatogenesis (Erdost et al., 2009). Histology findings of improved testicular function have been linked to red pepper's ability to increase FSH activity and the proliferation of spermatogenic cells and Leydig cells linked to testosterone (Erdost et al., 2006), in addition to presenting with antioxidant properties (Materska \& Perucka, 2005; Liu \& Nair, 2010). Yaji is a spice with super antioxidant activity, since each of its constituent spices has high antioxidant and pro-spermatogenic properties. Testicular histology of rats given Yaji revealed the presence of all spermatogenic cells and absence of atrophy in the seminiferous tubules that might disturb spermatogenesis (Ahmed-Farid et al., 2017).

Rats in the group given Yaji had appreciable wavelike or brush-like border appearance of the spermatids in the adluminal compartment of the ST, similar to those displayed in the testes of rats treated with red pepper and black pepper, leading to an increased number of sperm cells and thus demonstrating that Yaji, red pepper, black pepper, and ginger may improve fertility and enhance reproductive performance (Ahmed-Farid et al., 2017). Spermatogenesis is an energy-dependent process that requires a significant intake of antioxidants, minerals, vitamins, and flavonoids (Ogungbemi, 2006). In this present investigation, the increased level of testosterone may have been caused by the zinc and antioxidant properties present in Yaji and its constituent spices, which may have also been responsible for the improvement in the histological architecture of the testes of the rats (Sutyarso et al., 2015; Zodape \& Gaikwad, 2019). Zinc supplementation can improve the antioxidant status and increase serum levels of sex hormones, including testosterone in rats (Kumar \& Singh, 2015).

\section{CONCLUSION}

Yaji is imbued with pro-fertility potential that manifests itself via improvements in male fertility function associated with Leydig cell proliferation, increased synthesis of testosterone, enhanced spermatogenesis, and consequently improved sperm counts and motility. This study provided scientific support to the relevance and potential therapeutic applications of Yaji in male fertility enhancement.

\section{ACKNOWLEDGEMENT}

The authors acknowledge the support from the Anatomy Department of the University of Lagos Nigeria and its Histology Unit for providing the facilities in which specimens were processed and photomicrographs were taken.

\section{CONFLICT OF INTEREST}

The authors have no conflict of interest to declare.

\section{Corresponding author:}

Adejoke Elizabeth Memudu

Department of Anatomy

Faculty of Basic Medical Sciences

Edo State University Uzairue

(formerly Edo University Iyamho)

Edo State - Nigeria

E-mail: jokememudu@gmail.com adejoke.elizabeth@edouniversity.edu.ng

\section{REFERENCES}

Abarikwu So. Causes and risk factors for male-factor infertility in Nigeria: a review. Afr J Reprod Health. 2013;17:150-66. PMID: 24558791

Ademoyegun OT, Fariyike TA, Aminu-Taiwo RB. Effects of poultry dropping on the biologically active compounds in capsicum annuum L (var. Nsukka yellow). Agric Biol J N Am. 2011;2:665-72. DOI: 10.5251/abjna.2011.2.4.665.672

Agbaje EO, Adeneye AA, Daramola AO. Biochemical and toxicological studies of aqueous extract of Syzigium aromaticum (L.) Merr. \& Perry (Myrtaceae) in rodents. Afr J Tradit Complement Altern Med. 2009;6:241-54. PMID: 20448849 DOI: $10.4314 /$ ajtcam.v6i3.57162

Agbo EG, Nwaopara AO, Festus OO, Odike MA, Nosakhare IO. A relative study on weight changes and notable physical observations in adult albino Wistar rats fed with YAJI (A complex meat sauce). Int J Basic Appl Innov Res. 2013;2:92-9.

Agrawal RC, Bhide SV. Biological studies on carcinogenicity of chillies in Balb/c mice. Indian J Med Res. 1987;86:3916. PMID: 3428973

Ahmad N, Fazal H, Abbasi BH, Farooq S, Ali M, Khan MA. Biological role of Piper nigrum L. (Black pepper): A review. Asian Pac J Trop Biomed. 2012;2:S1945-53. DOI: 10.1016/S2221-1691(12)60524-3

Ahmed-Farid $\mathrm{OAH}$, Nasr M, Ahmed RF, Bakeer RM. Beneficial effects of curcumin nano-emulsion on spermatogenesis and reproductive performance in male rats under protein deficient diet model: enhancement of sperm motility, conservancy of testicular tissue integrity, cell energy and seminal plasma amino acids content. J Biomed Sci. 2017;24:66. PMID: 28865467 DOI: 10.1186/s12929-0170373-5

Akpamu U, Nwaopara AO, Izunya AM, Oaikhena GA, Okhiai $\mathrm{O}$, Idonije BO, Osifo UC. Comparative Study of the acute and chronic effects of Oral Administration of Yaji (A Complex Nigerian Meat Sauce) on Some Histological Parameters. Br J Pharmacol Toxicol. 2011a;3:108-12. 
Akpamu U, Nwaopara AO, Izunya AM, Oaikhena GA, Okhiai $\mathrm{O}$, Idonije BO, Osifo UC. A comparative study on Weight changes in rats fed with diet containing Yaji, Yaji additives, and Yaji Spices. Biol Med. 2011b;3:6-15.

Alley TR, Burroughs WJ. Do Men Have Stronger Preferences for Hot, Unusual, and Unfamiliar Foods? J Gen Psychol. 1991;118:201-14. PMID: 28142506 DOI: 10.1080/00221309.1991.9917781

Babaei Garmkhany S, Yousofvand N. Effects of Oral Administration of Red Pepper (Capsicum annuum) and Black Pepper (Piper nigrum) Powders on Plasma Levels of Pituitary - gonads Axis Hormones in Male Mice. J Med Plants. $2015 ; 14: 45-54$.

Bancroft JD, Gamble M, eds. Theory and Practice of Histologic Techniques. 5th ed. London: Churchill Livingstone; 2008.

Bhargava A, Guthrie JF. Unhealthy eating habits, physical exercise and macronutrient intakes are predictors of anthropometric indicators in the Women's Health Trial: Feasibility Study in Minority Populations. Br J Nutr. 2002;88:71928. PMID: 12493094 DOI: 10.1079/BJN2002739

Cheah Y, Yang W. Functions of essential nutrition for high quality spermatogenesis. Adv Biosci Biotechnol. 2011;2:182-97. DOI: 10.4236/abb.2011.24029

Chinta G, Coumar MS, Periyasamy L. Reversible Testicular Toxicity of Piperine on Male Albino Rats. Pharmacogn Mag. 2017;13:S525-32. PMID: 29142409 DOI: 10.4103/ pm.pm_405_16

D'Cruz SC, Mathur PP. Effects of piperine on the epididymis of adult male albino rats. Asian J Androl. 2005;7:363-8. PMID: 16281082 DOI: 10.1111/j.17457262.2005.00059.x

Ekaputri TW, Sari IP, Rizal DM. The Effect of Ethanol Extract of Piper nigrum L. Fruit on Reproductive System in Adult Male Wistar Rats: A Study of FSH, LH, Testosterone Level, and Spermatogenic Cells. Indonesian J Pharm. 2018;29:136-44.

Erdost $\mathrm{H}$, Özer A, Yakişik M, Özfiliz N, Zik B. FSH, and LH cells in the laying hens and cocks, fed with a diet containing red hot pepper. J Food Agric Environ. 2006;4:119-23.

Erdost H, Akkoc CGÖ, Özfiliz N, İlhan T, Tütüncü S. The histological investigation on the testes of mice after an application of capsaicin. Vet Arh. 2009;79:509-16.

Erhirhie EO. Chemical Composition and Biological Effects of Yaji: A Popular Nigerian Composite Suya Sauce. Trends Appl Sci Res. 2019;14:215-25. DOI: 10.3923/ tasr.2019.215.225

Eskenazi B, Kidd SA, Marks AR, Sloter E, Block G, Wyrobek AJ. Antioxidant intake is associated with semen quality in healthy men. Hum Reprod. 2005;20:1006-12. PMID: 15665024 DOI: $10.1093 /$ humrep/deh725

Eslamian G, Amirjannati N, Rashidkhani B, Sadeghi MR, Hekmatdoost A. Intake of food groups and idiopathic asthenozoospermia: a case-control study. Hum Reprod. 2012;27:3328-36. PMID: 22940769 DOI: 10.1093/humrep/des311
Ezejindu DN, Ezissi AI, Edokwe CG. The effects of Yaji on the histology of the kidney of adult Wistar rats. Int J Med Health Prof Res. 2014;1:8-14.

Final report on the safety assessment of capsicum annuum extract, capsicum annuum fruit extract, capsicum annuum resin, capsicum annuum fruit powder, capsicum frutescens fruit, capsicum frutescens fruit extract, capsicum frutescens resin, and capsaicin. Int J Toxicol. 2007;26:3-106. PMID: 17365137 DOI: 10.1080/10915810601163939

Gromadzka-Ostrowska J. Effects of dietary fat on androgen secretion and metabolism. Reprod Biol. 2006;6:13-20. PMID: 17220937

Guzick DS, Overstreet JW, Factor-Litvak P, Brazil CK, Nakajima ST, Coutifaris C, Carson SA, Cisneros P, Steinkampf MP, Hill JA, Xu D, Vogel DL; National Cooperative Reproductive Medicine Network. Sperm morphology, motility, and concentration in fertile and infertile men. N Engl J Med. 2001;345:1388-93. PMID: 11794171 DOI: 10.1056/NEJMoa003005

Hammami I, Nahdi A, Mauduit C, Benahmed M, Amri M, Ben Amar A, Zekri S, El May A, El May MV. The inhibitory effects on adult male reproductive functions of crude garlic (Allium sativum) feeding. Asian J Androl. 2008;10:593-601. PMID: 18097508 DOI: $10.1111 /$ j.1745-7262.2008.00358.x

Hammami I, Amara S, Benahmed M, El May MV, Mauduit C. Chronic crude garlic-feeding modified adult male rat testicular markers: mechanisms of action. Reprod Biol Endocrinol. 2009;7:65. PMID: 19552815 DOI: https://doi. org/10.1186/1477-7827-7-65

Hassan DI, Ogah DM, Yusuf ND, Musa MM, Saidu GM. The effect of acute and chronic (short and long term) oral administrations of black pepper (Piper guineense) aqueous extract on the body weight and hematological values of albino-Wistar rat. J Med Plant Res. 2010;4:1122-5.

Hosseini SE. Therapeutic Effects of Medicinal Herbs on Reproductive System Disorders: A Review. Rep Health Care. 2018;4:67-76.

Igene JO, Mohammed ID. Consumers' preferences and attitudes to Suya - an indigenous Nigerian meat product. Ann Borno. 1983;1:169-76.

Jaganathan SK, Supriyanto E. Antiproliferative and molecular mechanism of eugenol-induced apoptosis in cancer cells. Molecules. 2012;17:6290-304. PMID: 22634840 DOI: $10.3390 /$ molecules 17066290

Jahan S, Saeed N, Ijlal F, Khan MA, Ahmad M, Zafar M, Abbasi AM. Histomorphological study to evaluate anti-fertility effect of Abrus precatorius $L$ in adult male mice. J Med Plants Res. 2009;3:1021-8.

Jequier AM. Semen analysis: a new manual and its application to the understanding of semen and its pathology. Asian J Androl. 2010;12:11-3. PMID: 20111075 DOI: 10.1038/aja.2009.12

Kabuto H, Tada M, Kohno M. Eugenol [2-methoxy-4-(2-propenyl)phenol] prevents 6-hydroxydopamine-induced dopamine depression and lipid peroxidation inductivity in mouse striatum. Biol Pharm Bull. 2007;30:423-7. PMID: 17329831 DOI: $10.1248 /$ bpb. 30.423 
Kochhar KP. Dietary spices in health and diseases: I. Indian J Physiol Pharmacol. 2008;52:106-22. PMID: 19130854

Kopelman PG, Caterson I. An overview of obesity management. In: Kopelman PG, Caterson ID, Michael J. Stock, Dietz WH, eds. Clinical Obesity in Adults and Children. Blackwell Publishing; 2005. p. 317-26.

Krishnaswamy K, Raghuramulu N. Bioactive phytochemicals with emphasis on dietary practices. Indian J Med Res. 1998; 108:167-81. PMID: 9863273

Kumar N, Singh AK. Trends of male factor infertility, an important cause of infertility: A review of literature. J Hum Reprod Sci. 2015;8:191-6. PMID: 26752853 DOI: $10.4103 / 0974-1208.170370$

Liu Y, Nair MG. Capsaicinoids in the hottest pepper Bhut Jolokia and its antioxidant and antiinflammatory activities. Nat Prod Commun. 2010;5:91-4. PMID: 20184029 DOI: $10.1177 / 1934578 \times 1000500122$

Lo C. Integrating nutrition as a theme throughout the medical school curriculum. Am J Clin Nutr. 2000;72:882S-9S. PMID: 10966917 DOI: $10.1093 / a j c n / 72.3 .882 \mathrm{~s}$

Macpherson LJ, Geierstanger BH, Viswanath V, Bandell M, Eid SR, Hwang S, Patapoutian A. The pungency of garlic: activation of TRPA 1 and TRPV1 in response to allicin. Curr Biol. 2005;15:929-34. PMID: 15916949 DOI: 10.1016/j. cub.2005.04.018

Maina MB, Garba SH, Jacks TW. Histological evaluation of the rats' testis following administration of a herbal tea mixture. J Pharmacol Toxicol. 2008;3:464-70. DOI: 10.3923/ jpt.2008.464.470

Maneesh M, Jayalekshmi H, Dutta S, Chakrabarti A, Vasudevan DM. Role of oxidative stress in ethanol induced germ cell apoptosis - An experimental study in rats. Indian J Clin Biochem. 2005;20:62-7. PMID: 23105535 DOI: 10.1007/BF02867402

Materska M, Perucka I. Antioxidant activity of the main phenolic compounds isolated from hot pepper fruit (Capsicum annuum L). J Agric Food Chem. 2005;53:1750-6. PMID: 15740069 DOI: $10.1021 /$ jf035331k

Mbongue FGY, Kamtchouing $\mathrm{P}$, Essame OJL, Yewah PM, Dimo T, Lontsi D. Effect of the aqueous extract of dry fruits of Piper guineense on the reproductive function of adult male rats. Indian J Pharmacol. 2005;37:30-2. DOI: 10.4103/0253-7613.13852

McGee $\mathrm{H}$, ed. Food and cooking: The science and lore of kitchen. New York: Scribner Book Company; 2004.

Meghwal M, Goswami TK. Chemical composition, nutritional, medicinal, and functional properties of black pepper: A review. Open Access Sci Rep. 2012;1:172.

Memudu AE, Akinrinade ID, Ogundele OM. Retention of testicular integrity and testosterone levels upon ingestion of garlic cloves (Allium sativum) in the Sprague-Dawley rat. Asian Pac J Trop Biomed. 2015;5:319-23. DOI: 10.1016/ S2221-1691(15)30351-8
Micheal A, Folaranmi O, Ajoke O, Olatunji A, Oluwole A, Adewumi A. Effects of ginger (Zingiber officinale Roscoe) and garlic (Allium sativum L.) on rats infected with Kleibsiella pneumoniae. Internet J Altern Med. 2008;7:1-5.

Mishra RK, Singh SK. Antispermatogenic and antifertility effects of fruits of Piper nigrum L. in mice. Indian J Exp Biol. 2009;47:706-14. PMID: 19957882

National Research Council (US) Committee for the Update of the Guide for the Care and Use of Laboratory Animals. Guide for the Care and Use of Laboratory Animals, 8th ed. Washington (DC): National Academies Press; 2011.

Nirogi R, Goyal VK, Jana S, Pandey SK, Gothi A. What suits best for organ weight analysis: Review of relationship between organ weight and body/brain weight for rodent toxicity studies. Int J Pharm Sci Res. 2014;5:1525-32.

Nwaopara AO, Anyanwu LC, Oyinbo CA, Anaikot IC. The Histological Changes in Pancreas of Wister Rats Fed with Diets Containing Yaji (Local Meat Sauce). J Expt Clin Anat. 2004;3:44-7.

Nwaopara AO, Odike MAC, Inegbenebor $U$, Adoye MI. The Combined effects of excessive consumption of ginger, clove, red pepper, and black pepper on the histology of the liver. Pak J Nutr. 2007;6:524-7. DOI: 10.3923/ pjn.2007.524.527

Nwaopara AO, Odike MAC, Inegbenebor U, Nwaopara SO, Ewere GI. A comparative study on the effects of excessive consumption of ginger, clove, red pepper, and black pepper on the histology of the Kidney. Pak J Nutr. 2008;7:287-91. DOI: $10.3923 /$ pjn.2008.287.291

Nwaopara AO, Anibeze CIP, Akpuaka FC. Histological Signs of Oligodendroglioma in the Brain of Rats Fed with Diet Containing Yaji: The Complex Nigerian Suya Meat Sauce. Clin Rev Opinions. 2009;1:21-5.

Nwaopara AO, Anibeze CIP, Akpuaka FC. Histological Signs of Neurodegeneration in The Cerebrum of Rats Fed with Diet Containing Yaji: The Complex Nigerian Suya Meat Sauce. Asian J Med Sci. 2010;2:16-21. DOI: 10.5897/ CRO. 9000015

Ogbuewu IP, Unamba-Oparah IC, Odoemenam VU, Etuk IF, Okoli IC. The potentiality of medicinal plants as the source of new contraceptive principles in males. N Am J Med Sci. 2011;3:255-63. PMID: 22540095 DOI: 10.4297/ najms.2011.3250

Ogungbemi T, ed. Outlines and pictures of medicinal plants in Nigeria. Lagos: University of Lagos Press; 2006.

Ogwo EU, Osim EE, Nwankwo AA, Ijioma SN, Ngwu EE. Acute toxicity study and hormone profile enhancing activity of Pausinystalia yohimbe bark powder (Burantashi) in in vivo experimental animal models. Com J Med Sci. $2016 ; 3: 20-7$.

Okereke C, Onuoha S. Effect of ethanolic extract of Cannabis sativa on progesterone and estrogen hormones in female Wistar rats. Reprod Sys Sex Disord. 2015;4:150-3. DOI: $10.4172 / 2161-038 X .1000150$ 
Okonkwo TM. About yaji and suya. J Food Agric. 1987;1:51.

Omojola $A B$. Yield and organoleptic characteristics of suya (an intermediate moisture meat product meat) prepared from three different muscles of a matured bull. Afr J Biotechnol. 2008;7:2254-7. DOI:10.4314/ajb.v7i13.58968

Orieke D, Ohaeri OC, Irene Ijeh I, Ijioma SN. Semen quality, hormone profile and histological changes in male albino rats treated with Corchorus olitorius leaf extract. Avicenna J Phytomed. 2019;9:551-62. PMID: 31763214 DOI: 10.22038/AJP.2019.13426

Payne $\mathrm{AH}$, O'Shaughnessy PJ. Structure, function and regulation of steroidogenic enzymes in the Leydig cell. In: Payne AH, Hardy MP, Russell LD, eds. The Leydig Cell. Vienna: Cache River Press; 1996. p. 263-75.

Prasad MR, Rajalakshmi M. Comparative physiology of the mammalian epididymis. Gen Comp Endocrinol. 1976;28:530-7. PMID: 821810 DOI: 10.1016/00166480(76)90160-X

Quesada I, de Paola M, Torres-Palazzolo C, Camargo A, Ferder L, Manucha W, Castro C. Effect of Garlic's Active Constituents in Inflammation, Obesity and Cardiovascular Disease. Curr Hypertens Rep. 2020;22:6. PMID: 31925548 DOI: $10.1007 / \mathrm{s} 11906-019-1009-9$

Rahmawati N, Bachri MN. The aphrodisiac effect and toxicity of combination Piper retrofractum L, Centella asiati$\mathrm{ca}$, and Curcuma domestica infusion. Health Sci J Indones. 2012;3:19-22. DOI: 10.22435/hsji.v3i1 Jun.421.19-22

Rajalakshmi M. Regulation of male fertility: Epididymis as a potential extragonadal site. In: Ghosh D, Sengupta J, eds. Frontiers in reproductive physiology. New Delhi: Wiley Eastern Limited; 1992. p. 63-6.

Raji Y, Ifabunmi OS, Akinsomisoye OS, Morakinyo AO, Oloyo AK. Gonadal responses to antipsychotic drugs: Chlorpromazine and thioridazine reversibly suppress testicular functions in albino rats. Int J Pharmacol. 2005;1:287-92. DOI: 10.3923/ijp.2005.287.292

Robbins WA, Xun L, FitzGerald LZ, Esguerra S, Henning SM, Carpenter CL. Walnuts improve semen quality in men consuming a Western-style diet: randomized control dietary intervention trial. Biol Reprod. 2012;87:101. PMID: 22895856 DOI: $10.1095 /$ biolreprod.112.101634

Safarinejad MR, Hosseini SY, Dadkhah F, Asgari MA. Relationship of omega-3 and omega- 6 fatty acids with semen characteristics, and anti-oxidant status of seminal plasma: a comparison between fertile and infertile men. Clin Nutr. 2010;29:100-5. PMID: 19666200 DOI: 10.1016/j. clnu.2009.07.008

Scherer R, Wagner R, Duarte M, Godoy HT. Composition and antioxidant and antimicrobial activities of clove, citronella and palmarosa essential oils. Rev Bras Plantas Med. 2009;11:442-9. DOI: 10.1590/S151605722009000400013

Sembulingam K, Prema S, eds. Essential of medical physiology. 7th ed. New Delhi: Jaypee Brothers; 2016.
Sim KH, Sil HV. Antioxidant activities of red pepper (Capsicum annuum) pericarp and seed extracts. Int J Food Sci Nutr Technol. 2008;43:1813-23. DOI: $10.1111 /$ j.13652621.2008.01715.x

Simmons JE, Yang RS, Berman E. Evaluation of the nephrotoxicity of complex mixtures containing organics and metals: advantages and disadvantages of the use of real-world complex mixtures. Environ Health Perspect. 1995;103:6771. PMID: 7621803 DOI: 10.1289/ehp.95103s167

Sinclair S. Male infertility: nutritional and environmental considerations. Altern Med Rev. 2000;5:28-38. PMID: 10696117

Southgate DAT. Spices and Beverages. In: Garrow JS, James WPT, eds. Human Nutrition and Dietetics. Edinburg: Churchill Livingstone; 1993. p. 325-34.

Surh YJ, Lee SS. Capsaicin, a double-edged sword: toxicity, metabolism, and chemopreventive potential. Life Sci. 1995;56:1845-55. PMID: 7746093 DOI: 10.1016/00243205(95)00159-4

Sutyarso M, Kanedi M, Rosa E. Effects of Black Pepper (Piper nigrum Linn.) Extract on Sexual Drive in Male Mice. Res J Med Plants. 2015;9:42-7. DOI: 10.3923/rjmp.2015.42.47

Ugbogu OC, Ogodo AC, Ameh BO. Some microorganisms associated with ginger-based Yaji in Wukari metropolis. Int Food Res J. 2018;25:1703-7.

Ugwuja EI, Ugwu NC, Nwibo AN. Dietary supplement containing a mixture of raw curry, garlic, and ginger. Internet J Nutr Wellness. 2007;5:1-5.

Ukoha UU, Egwu OA, Dimkpa U, Maduka SO, Okafor J, Ndukwe GU, Ogonnadi K. Histological and weight changes in Testes of Male Albino Rats Fed with Diets Containing Yaji (A local Meat Sauce). Int J Health Sci Res. 2014;4:118-26.

Uzeh RE, Ohenhen RE, Adeniji OO. Bacterial contamination of Tsire-Suya, a Nigerian meat product. Pak J Nutr. 2006;5:458-60. DOI: 10.3923/pjn.2006.458.460

Vasan SS. Semen analysis and sperm function tests: How much to test? Indian J Urol. 2011;27:41-8. PMID: 21716889 DOI: $10.4103 / 0970-1591.78424$

Vijayakumar RS, Surya D, Nalini N. Antioxidant efficacy of black pepper (Piper nigrum L.) and piperine in rats with high fat diet induced oxidative stress. Redox Rep. 2004; 9:10510. PMID: 15231065 DOI: $10.1179 / 135100004225004742$

Viuda-Martos M, Navajas YR, Zapata ES, Fernández-López J, Pérez-Álvarez JA. Antioxidant activity of essential oils of five spice plants widely used in a Mediterranean diet. Flavour Fragr J. 2010;25:13-9. DOI: 10.1002/ffj.1951

Wall LL. Dead mothers and injured wives: the social context of maternal morbidity and mortality among the Hausa of northern Nigeria. Stud Fam Plann. 1998;29:341-59. PMID: 9919629 DOI: $10.2307 / 172248$

Wallen K. Sex and context: hormones and primate sexual motivation. Horm Behav. 2001;40:339-57. PMID: 11534996 DOI: $10.1006 /$ hbeh.2001.1696 
Wichtl M. Herbal drugs and phytopharmaceuticals. 3rd ed. Boca Raton: CRC Press; 2004.

World Health Organization (WHO). WHO Laboratory Manual for the Examination of the Human Semen. 5th ed. Geneva: World Health Organization; 2010.

Sinclair S. Male infertility: nutritional and environmental considerations. Altern Med Rev. 2000;5:28-38. PMID: 10696117

Southgate DAT. Spices and Beverages. In: Garrow JS, James WPT, eds. Human Nutrition and Dietetics. Edinburg: Churchill Livingstone; 1993. p. 325-34.

Surh YJ, Lee SS. Capsaicin, a double-edged sword: toxicity, metabolism, and chemopreventive potential. Life Sci. 1995;56:1845-55. PMID: 7746093 DOI: 10.1016/00243205(95)00159-4

Sutyarso M, Kanedi M, Rosa E. Effects of Black Pepper (Piper nigrum Linn.) Extract on Sexual Drive in Male Mice. Res J Med Plants. 2015;9:42-7. DOI: 10.3923/rjmp.2015.42.47

Ugbogu OC, Ogodo AC, Ameh BO. Some microorganisms associated with ginger-based Yaji in Wukari metropolis. Int Food Res J. 2018;25:1703-7.

Ugwuja EI, Ugwu NC, Nwibo AN. Dietary supplement containing a mixture of raw curry, garlic, and ginger. Internet J Nutr Wellness. 2007; 5:1-5.

Ukoha UU, Egwu OA, Dimkpa U, Maduka SO, Okafor J, Ndukwe GU, Ogonnadi K. Histological and weight changes in Testes of Male Albino Rats Fed with Diets Containing Yaji (A local Meat Sauce). Int J Health Sci Res. 2014;4:118-26.

Uzeh RE, Ohenhen RE, Adeniji OO. Bacterial contamination of Tsire-Suya, a Nigerian meat product. Pak J Nutr. 2006;5:458-60. DOI: 10.3923/pjn.2006.458.460

Vasan SS. Semen analysis and sperm function tests: How much to test? Indian J Urol. 2011;27:41-8. PMID: 21716889 DOI: $10.4103 / 0970-1591.78424$
Vijayakumar RS, Surya D, Nalini N. Antioxidant efficacy of black pepper (Piper nigrum L.) and piperine in rats with high fat diet induced oxidative stress. Redox Rep. 2004;9:105-10. PMID: 15231065 DOI: $10.1179 / 135100004225004742$

Viuda-Martos M, Navajas YR, Zapata ES, Fernández-López J, Pérez-Álvarez JA. Antioxidant activity of essential oils of five spice plants widely used in a Mediterranean diet. Flavour Fragr J. 2010;25:13-9. DOI: 10.1002/ffj. 1951

Wall LL. Dead mothers and injured wives: the social context of maternal morbidity and mortality among the Hausa of northern Nigeria. Stud Fam Plann. 1998;29:341-59. PMID: 9919629 DOI: $10.2307 / 172248$

Wallen K. Sex and context: hormones and primate sexual motivation. Horm Behav. 2001;40:339-57. PMID: 11534996 DOI: $10.1006 /$ hbeh.2001.1696

Wichtl M. Herbal drugs and phytopharmaceuticals. 3rd ed. Boca Raton: CRC Press; 2004.

World Health Organization (WHO). WHO Laboratory Manual for the Examination of the Human Semen. 5th ed. Geneva: World Health Organization; 2010.

Wright CA. Some Like It Hot: Spicy Favorites From The World's Hot Zones. Boston: Harvard Common Press; 2005.

Yang C, Li L, Yang L, Lü H, Wang S, Sun G. Anti-obesity and Hypolipidemic effects of garlic oil and onion oil in rats fed a high-fat diet. Nutr Metab (Lond). 2018;15:43. PMID: 29951108 DOI: https://doi.org/10.1186/s12986018-0275-x

Zodape GV, Gaikwad VS. Effect of Piper nigrum (linn.) on infertility induced by ethionamide and para aminosalicylic acid in male Sprague-Dawley rats. Int J Pharm Sci Res. 2019;10:5160-66. DOI: 10.13040/ IJPSR.0975-8232.10(11).5160-66 